\title{
Congenital Malformation Syndrome
}

National Cancer Institute

\section{Source}

National Cancer Institute. Congenital Malformation Syndrome. NCI Thesaurus. Code C99267.

A syndrome characterized by the presence of congenital abnormalities that affect more than one organ or system. 